Research Article

\title{
From Synthesis to Biological Impact of Pd (II) Complexes: Synthesis, Characterization, and Antimicrobial and Scavenging Activity
}

\author{
Nitin Kumar Sharma, Rakesh Kumar Ameta, and Man Singh \\ School of Chemical Sciences, Central University of Gujarat, Gandhinagar 382030, India \\ Correspondence should be addressed to Man Singh; mansingh50@hotmail.com
}

Received 12 October 2015; Accepted 23 February 2016

Academic Editor: Robert J. Linhardt

Copyright (C) 2016 Nitin Kumar Sharma et al. This is an open access article distributed under the Creative Commons Attribution License, which permits unrestricted use, distribution, and reproduction in any medium, provided the original work is properly cited.

The Pd (II) complexes with a series of halosubstituted benzylamine ligands (BLs) have been synthesized and characterized with different spectroscopic technique such as FTIR, UV/Vis, LCMS, ${ }^{1} \mathrm{H}$, and ${ }^{13} \mathrm{C}$ NMR. Their molecular sustainability in different solvents such as DMSO, DMSO : $\mathrm{H}_{2} \mathrm{O}$, and DMSO : PBS at physiological condition ( $\mathrm{pH}$ 7.2) was determined by UV/Vis spectrophotometer. The in vitro antibacterial and antifungal activities of the complexes were investigated against Gram-positive and Gram-negative microbes and two different fungi indicated their significant biological potential. Additionally, their antioxidant activity has been analyzed with $\mathrm{DPPH}^{*}$ free radical through spectrophotometric method and the result inferred them as an antioxidant. The stronger antibacterial and antioxidant activities of the synthesized complexes suggested them as a stronger antimicrobial agent. Our study advances the biological importance of palladium (II) amine complexes in the field of antimicrobial and antioxidant activities.

\section{Introduction}

After a tremendous discovery of cisplatin, the synthesis and biological evaluation of new transition metal-based compounds are fields of growing interest [1]. The palladium (II) as nonplatinum metal complexes highly attracted the researchers because of its significant biological activity as well as lower side effects along with higher lipophilicity or solubility compared to cisplatin [2-5]. Palladium metal is a suitable candidate for metallodrugs because it displays structural properties similar to those of platinum and also exhibits promising in vitro cytotoxicity. Numerous Pd (II) complexes with different benzylamine ligands have been synthesized and their interesting in vitro biological activities have been reported $[6,7]$. The antimicrobial activity of different palladium (II) complexes on the growth and metabolism of various groups of microorganisms has been studied and reported elsewhere. Garoufis et al. reviewed numerous scientific papers on antiviral, antibacterial, and antifungal activity of Pd (II) complexes with different types of ligands (sulfur and nitrogen donor ligands, Schiff base ligands, and different drugs as ligands) [8]. There are other interesting works which are reported recently in the literature showing different intensities of palladium complex activity on various species of bacteria and fungi [9-15]. In view of the growing cases of drug resistance of microorganisms it is urgent to search for more biospecific antifungal, less toxic agents. Metal-based drugs might answer this claim, representing an alternative therapeutic route. In this context, the discovery of nonplatinum based metal complexes came into consideration [16].

The aim of this paper is to synthesize new series of palladium (II) complexes and evaluate their in vitro antibacterial and antifungal activities against different microbes. The main aim of this research is focused on the biological impact of the newly synthesized Pd (II) complexes on different microorganism like Gram-positive and Gram-negative bacteria and different fungi. Hence, our study is an attempt to get overcome from microbial disease up to some extent. So 
with the aforesaid objectives we have synthesized new Pd (II) with halo substituted BLs and analyzed in vitro antimicrobial, antifungal, and antioxidant activity.

\section{Experimental Section}

2.1. Materials and Methods. Palladium dichloride $\left(\mathrm{PdCl}_{2}\right)$, benzylamine ligands (BLs), DMSO, and ethanol (>99.5\%) were purchased from Sigma Aldrich and used without further modifications. Elemental analysis was made with a Euro vector CHN analyzer, and UV/Vis spectra were recorded with a Spectro 2060 plus spectrophotometer over 200-600 nm in a $1 \mathrm{~cm}$ path length cuvette. FTIR (Perkin Elmer) spectra were taken with $\mathrm{KBr}$ palate where polystyrene thin film was used as a calibration standard. ${ }^{1} \mathrm{H}$ and ${ }^{13} \mathrm{C}$ NMR spectra were recorded in DMSO-d6 (NMR, 99.99\%) with a BrukerBiospin Avance-III $500 \mathrm{MHz}$ FT-NMR spectrometer. Mass spectra were obtained with PE SCIEX API 165 with +ve ESI mode with ammonium acetate and acetonitrile in 1:9 v/v ratio as mobile phase. The molecular sustainability of Pd (II) complexes was determined by preparing a solution in DMSO, DMSO : water, and DMSO : phosphate buffer of $\mathrm{pH}$ 7.2. Buffer solution was prepared by adding $70 \mathrm{~mL} 0.1 \mathrm{M}$ aqueous $\mathrm{NaOH}$ to $0.1 \mathrm{M}$ aqueous $\mathrm{KH}_{2} \mathrm{PO}_{4}$ solution. The $\mathrm{pH}$ of a resultant buffer was checked with RS-232 modelled CyberScan $\mathrm{pH}$ 2100, EUTECH pH meter.

2.2. General Consideration for Synthesis. Initially, $\mathrm{PdCl}_{2}$ and BLs (molar ratio 1:2, resp.) were separately dissolved in freshly prepared solvent (absolute ethanol and Milli-Q water in $1: 1.5)$ using $1 \mathrm{MLH}$ magnetic stirrer. Then, the BLs solutions were added dropwise to metal compound solution with continuous stirring at room temperature. After $10 \mathrm{~h}$, the mixture turned from light red brown to greenish color and after $16 \mathrm{~h}$, precipitates were formed. The precipitates were filtered off, washed several times with chilled water/ethanol in 1:1 ratio, and kept overnight in vacuum oven at room temperature for absolute dryness.

\subsection{Characterization Data}

2.3.1. Complex 1: $\mathrm{C}_{14} \mathrm{H}_{15} \mathrm{~N}_{2} \mathrm{Cl}_{3} \mathrm{Pd}$ [Pd2CBA]. Yield: $0.1492 \mathrm{~g}$, 67.615\%. Elemental analysis, found: C, 39.65; $\mathrm{H}, 3.57 ; \mathrm{N}$, 6, 61\%. Calcd for $\mathrm{C}_{14} \mathrm{H}_{16} \mathrm{~N}_{2} \mathrm{Cl}_{2} \mathrm{Pd}$ : C, 40.01; $\mathrm{H}, 3.98 ; \mathrm{N}$, 7.88\%. IR (KBr): $v_{\max / \mathrm{cm}^{-1}} 3273$ and $3226\left(\mathrm{NH}_{2}\right), 1497$ and 1457 ( $\mathrm{Ph}, \mathrm{C}=\mathrm{C}$ ), 756.46 (mono substituted $\mathrm{Ph}$ ), $1075(\mathrm{C}-\mathrm{N})$, $567.4(\mathrm{Pd}-\mathrm{N}), 405.9$ (Pd-Cl). ${ }^{1} \mathrm{H} N \mathrm{NMR}(500 \mathrm{MHz}$; DMSO$\left.\mathrm{d}_{6} ; \mathrm{Me}_{4} \mathrm{Si}\right) \delta 3.74-3.80\left(2 \mathrm{H}, \mathrm{s}, \mathrm{PhCH}_{2} \mathrm{NH}_{2}\right), 4.06-4.10(2 \mathrm{H}$, s, $\left.\mathrm{PhCH}_{2} \mathrm{NH}_{2}\right), 7.43-7.45(1 \mathrm{H}, \mathrm{d}, \mathrm{PhH}, J=7.3 \mathrm{~Hz}), 7.72-7.75$ $(1 \mathrm{H}, \mathrm{d}, \mathrm{PhH}, J=6.5 \mathrm{~Hz})$ and $7.32-7.36(1 \mathrm{H}, \mathrm{t}, \mathrm{PhH}) .{ }^{13} \mathrm{C} \mathrm{NMR}$ (125 MHz; DMSO-d ; $\mathrm{Me}_{4} \mathrm{Si}$ ) $\delta 45.43$ (C1), 129.0 (C5), 129.2 (C4), 130.4 (C7), 132.2 (C3), 135.5 (C2), and 172.6 (C6). +ve ESI-MS: $424.93 \mathrm{~m} / z[\mathrm{M}+1]$ (calc. for $\left[\mathrm{C}_{14} \mathrm{H}_{13} \mathrm{~N}_{2} \mathrm{Cl}_{2} \mathrm{Pd}\right]=$ 424.03). $U V / V i s$ in DMSO: $\lambda_{\max }\left[\varepsilon\left(\mathrm{dm}^{3} \mathrm{~mol}^{-1} \mathrm{~cm}^{-1}\right)\right]=275$ (2066), 335 (265), 385 (221) nm, in DMSO : water (1:1): $\lambda_{\max }$ $\left[\varepsilon\left(\mathrm{dm}^{3} \mathrm{~mol}^{-1} \mathrm{~cm}^{-1}\right)\right]=265(2465)$, in DMSO:phosphate buffer (1:1): $\lambda_{\max }\left[\varepsilon\left(\mathrm{dm}^{3} \mathrm{~mol}^{-1} \mathrm{~cm}^{-1}\right)\right]=260$ (1514), 335 (288) $\mathrm{nm}$.
2.3.2. Complex 2: $\mathrm{C}_{14} \mathrm{H}_{15} \mathrm{~N}_{2} \mathrm{Cl}_{3} \mathrm{Pd}$ [Pd3CBA]. Yield: $0.1492 \mathrm{~g}$, $67.615 \%$. Elemental analysis, found: C, 39.24; $\mathrm{H}, 3.66 ; \mathrm{N}$, 6.43\%. Calcd for $\mathrm{C}_{14} \mathrm{H}_{15} \mathrm{~N}_{2} \mathrm{Cl}_{3} \mathrm{Pd}$ : C, 39.9; $\mathrm{H}, 4.11 ; \mathrm{N}, 6.88 \%$. IR $(\mathrm{KBr}): v_{\max / \mathrm{cm}^{-1}} 3273$ and $3226\left(\mathrm{NH}_{2}\right), 1497$ and $1457(\mathrm{Ph}$, $\mathrm{C}=\mathrm{C}), 756.46$ (mono substituted $\mathrm{Ph}), 1075(\mathrm{C}-\mathrm{N}), 567.4(\mathrm{Pd}-$ N), 405.9 (Pd-Cl). ${ }^{1} \mathrm{H}$ NMR $\left(500 \mathrm{MHz} ; \mathrm{DMSO}-\mathrm{d}_{6} ; \mathrm{Me}_{4} \mathrm{Si}\right) \delta$ 3.61-3.64 (2H, s, $\mathrm{PhCH}_{2} \mathrm{NH}_{2}$ ), 4.06-4.10 (2H, s, $\mathrm{PhCH}_{2} \mathrm{NH}_{2}$ ), $7.34-7.36(1 \mathrm{H}, \mathrm{d}, \mathrm{PhH}, J=7.3 \mathrm{~Hz}), 7.43-7.45(1 \mathrm{H}, \mathrm{d}, \mathrm{PhH}, J=$ $6.5 \mathrm{~Hz})$ and $7.57-7.59(1 \mathrm{H}, \mathrm{s}, \mathrm{PhH}) .{ }^{13} \mathrm{C} \mathrm{NMR}(125 \mathrm{MHz}$; DMSO-d ${ }_{6}$; $\mathrm{Me}_{4} \mathrm{Si}$ ) $\delta 45.59$ (C1), 129.74 (C5), 128.5 (C4), 129.4 (C7), 133.2 (C3), 136.5 (C2), and 174.6 (C6). +ve ESI-MS: $424.93 \mathrm{~m} / z[\mathrm{M}+1]$ (calc. for $\left[\mathrm{C}_{14} \mathrm{H}_{13} \mathrm{~N}_{2} \mathrm{Cl}_{2} \mathrm{Pd}\right]=424.03$ ). $U V /$ Vis in DMSO: $\lambda_{\max }\left[\varepsilon\left(\mathrm{dm}^{3} \mathrm{~mol}^{-1} \mathrm{~cm}^{-1}\right)\right]=275(2066)$, 335 (265), $385(221) \mathrm{nm}$, in DMSO: water (1:1): $\lambda_{\max }[\varepsilon$ $\left.\left(\mathrm{dm}^{3} \mathrm{~mol}^{-1} \mathrm{~cm}^{-1}\right)\right]=265(2465)$, in DMSO : phosphate buffer (1:1): $\lambda_{\max }\left[\varepsilon\left(\mathrm{dm}^{3} \mathrm{~mol}^{-1} \mathrm{~cm}^{-1}\right)\right]=260(1514) \mathrm{nm}$.

2.3.3. Complex 3: $\mathrm{C}_{14} \mathrm{H}_{15} \mathrm{~N}_{2} \mathrm{Cl}_{3} \mathrm{Pd}$ [Pd4CBA]. Yield: $0.1492 \mathrm{~g}$, 67.615\%. Elemental analysis, found: C, 39.88; $\mathrm{H}, 3.84 ; \mathrm{N}$, 6.66\%. Calcd for $\mathrm{C}_{14} \mathrm{H}_{15} \mathrm{~N}_{2} \mathrm{Cl}_{3} \mathrm{Pd}$ : C, 40.22; $\mathrm{H}, 4.93 ; \mathrm{N}$, 6.88\%. IR $(\mathrm{KBr}): v_{\max / \mathrm{cm}^{-1}} 3273$ and $3226\left(\mathrm{NH}_{2}\right), 1497$ and 1457 ( $\mathrm{Ph}, \mathrm{C}=\mathrm{C}$ ), 756.46 (mono substituted $\mathrm{Ph}$ ), $1075(\mathrm{C}-\mathrm{N})$, $567.4(\mathrm{Pd}-\mathrm{N}), 405.9$ (Pd-Cl). ${ }^{1} \mathrm{H} N M R(500 \mathrm{MHz}$; DMSO$\left.\mathrm{d}_{6} ; \mathrm{Me}_{4} \mathrm{Si}\right) \delta 3.58-3.61\left(2 \mathrm{H}, \mathrm{s}, \mathrm{PhCH}_{2} \mathrm{NH}_{2}\right), 4.00-4.03(2 \mathrm{H}$, s, $\left.\mathrm{PhCH}_{2} \mathrm{NH}_{2}\right), 7.37-7.39(1 \mathrm{H}, \mathrm{s}, \mathrm{PhH}) 7.50(1 \mathrm{H}, \mathrm{d}, \mathrm{PhH} J=$ $8.43 \mathrm{~Hz}, 1 \mathrm{H}) 7.49-7.51(1 \mathrm{H}, \mathrm{d}, \mathrm{PhH}, J=8.23 \mathrm{~Hz} 1 \mathrm{H}) .{ }^{13} \mathrm{C} \mathrm{NMR}$ (125 MHz; DMSO-d ; $_{\text {Me }} \mathrm{Si}$ ) $\delta 45.49$ (C1), 129.69 (C5), 129.47 (C4), 131.6 (C7), 131.4 (C3), 136.5 (C2), and 173.6 (C6). +ve ESI-MS: $424.93 \mathrm{~m} / z[\mathrm{M}+1]$ (calc. for $\left[\mathrm{C}_{14} \mathrm{H}_{13} \mathrm{~N}_{2} \mathrm{Cl}_{2} \mathrm{Pd}\right]=$ 424.03). $U V /$ Vis in DMSO: $\lambda_{\max }\left[\varepsilon\left(\mathrm{dm}^{3} \mathrm{~mol}^{-1} \mathrm{~cm}^{-1}\right)\right]=275$ (2066), 335 (265), 385 (221) nm, in DMSO : water (1:1): $\lambda_{\max }$ $\left[\varepsilon\left(\mathrm{dm}^{3} \mathrm{~mol}^{-1} \mathrm{~cm}^{-1}\right)\right]=265(2465) \mathrm{nm}$, in DMSO : phosphate buffer (1:1): $\lambda_{\max }\left[\varepsilon\left(\mathrm{dm}^{3} \mathrm{~mol}^{-1} \mathrm{~cm}^{-1}\right)\right]=265(1514) \mathrm{nm}$.

2.4. UV/Vis Spectroscopy. Electronic spectra were recorded with a Spectro 2060 plus model UV/Vis spectrophotometer from 200 to $600 \mathrm{~nm}$ using $1 \mathrm{~cm}$ path length cuvette. DMSO was used for solution preparation. The stability of compounds was determined by preparing a solution in DMSO, DMSO/water, and DMSO/phosphate buffer of pH 7.2. Buffer solution was prepared by adding $70 \mathrm{~mL} 0.1 \mathrm{M}$ aqueous $\mathrm{NaOH}$ solution to $0.1 \mathrm{M}$ aqueous $\mathrm{KH}_{2} \mathrm{PO}_{4}$ solution. The $\mathrm{pH}$ of the resultant buffer was checked with RS-232 modelled CyberScan pH 2100, EUTECH pH meter instrument. Their concentration for the UV study with DMSO, DMSO : water, and DMSO : PBS was kept constant at $1 \times 10^{-3} \mathrm{M}$.

2.5. HRTEM Images and SAED Pattern. The TEM images of the Pd2MBA were taken by HRTEM Jeol Jem 2100 at different magnification. The sample analysis was done by dispersing the sample in water and then dropped on carbon coated copper grid. After complete dryness of the sample on grid, the grid was inserted in specimen and then the images were taken. 


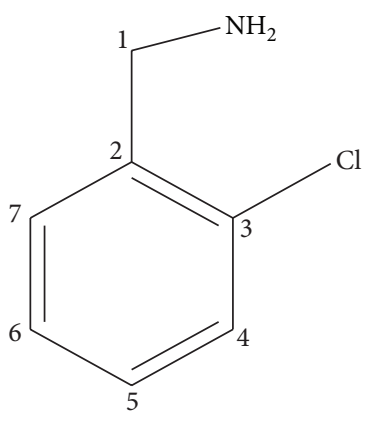

2-Chlorobenzylamine

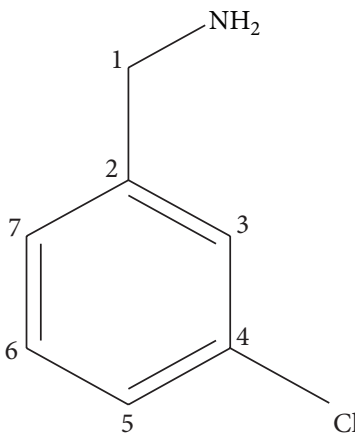

3-Chlorobenzylamine

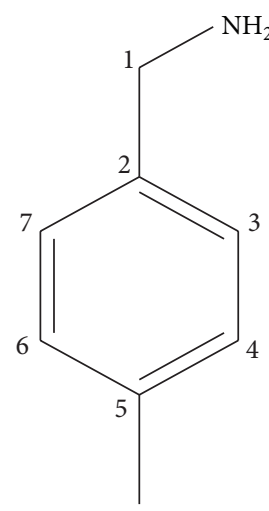

$\mathrm{Cl}$

4-Chlorobenzylamine

FIGURE 1: Structures of the ligands ( $\mathrm{L}=\mathrm{BLs})$.

\section{Biological Evaluation}

3.1. Microorganism Test. The synthesized palladium (II) complexes tested against 6 microbes for their biological potential. They screened their antibacterial activities against human pathogenic bacteria, namely, Gram-negative (Escherichia coli; NCIM 2109 and Pseudomonas aeruginosa; NCIM 2036) and Gram-positive (Staphylococcus aureus; NCIM 2079 and Bacillus subtilis; NCIM 2250) bacterial strains and two fungal strains (Candida albicans; NCIM 3471 and Aspergillus niger; NCIM 545) by Kirby Beurs Disc Diffusion Method using DMSO as solvent at $200 \mu \mathrm{gmL}^{-1}$ on Mueller Hinton Agar media. The zone of inhibition was measured in millimetre $(\mathrm{mm})$ after $24 \mathrm{~h}$ incubation at $37^{\circ} \mathrm{C}$ and $\mathrm{pH}$ 7.4. The zones of inhibition were compared with the standard drugs chloramphenicol $(10 \mu \mathrm{g})$ and ciprofloxacin $(10 \mu \mathrm{g})$. Discs with only DMSO were used as positive control.

3.2. Antioxidant Activities. Antioxidant activities have been studied on free radical scavenging of stable 1-2, 5- diphenyl2-picrylhydrazyl $\left(\mathrm{DPPH}^{\bullet}\right)$. For this purpose stock solution of complexes and $\mathrm{DPPH}^{\bullet}(0.002 \%)$ were mixed in DMSO + water $(1: 1)$ for $\mathrm{Pd}$ (II) complexes. For sample preparation, the $\mathrm{DPPH}^{\bullet}$ solution was mixed with a complex solution in $1: 1$, followed by vigorous shaking, and thereafter kept for incubation of $30 \mathrm{~min}$ in dark. The UV absorbance was measured at $517 \mathrm{~nm}$ with UV/Vis spectrophotometer and a decrease in $\mathrm{DPPH}^{\bullet}$ absorbance was noted which indicates a radical-scavenging activity calculated with the following equation:

$$
\text { Scavenging activity } \%=\left(\frac{A_{0}-A_{s}}{A_{0}}\right) \times 100 \text {. }
$$

$A_{S}$ is absorbance of $\mathrm{DPPH}^{\bullet}$ with a test compound and $A_{0}$ is absorbance of $\mathrm{DPPH}^{\bullet}$ without a test compound. Absorbance data are presented as means \pm SD of three determinations.

\section{Results and Discussion}

4.1. Synthesis and Characterization. $\mathrm{PdCl}(\mathrm{BLs})_{2}$ have been synthesized allowing reaction of $\mathrm{PdCl}_{2}$ with different BLs (Figure 1) in 1:2 molar ratio over $16 \mathrm{~h}$ as per Reaction Scheme. The ethanol + water solution in $1: 1.5$ ratios was used for the synthesis of all the complexes solution.

Reaction Scheme. Synthesis of Pd (II) complexes is as follows:

$$
\mathrm{PdCl}_{2}+2 \mathrm{BLs} \underset{16 \mathrm{~h} / \mathrm{rt}}{\stackrel{\text { Aqueous } \mathrm{C}_{2} \mathrm{H}_{5} \mathrm{OH}}{\longrightarrow}} \mathrm{PdCl}(\mathrm{BLs})_{2}
$$

The 3300 to $3119 \mathrm{~cm}^{-1}$ stretching frequencies inferred presence of $\mathrm{NH}_{2}$ of benzylamine ligands in the complexes and similarly from 1497 to $1453 \mathrm{~cm}^{-1}$ predicted $\mathrm{C}=\mathrm{C}$ in phenyl ring. The 495.92 to $438.78 \mathrm{~cm}^{-1}$ and $380-348 \mathrm{~cm}^{-1}$ bands indicate the $\mathrm{Pd}-\mathrm{N}$ and $\mathrm{Pd}-\mathrm{Cl}$ bands, respectively $[17,18]$. In ${ }^{1} \mathrm{H} \mathrm{NMR}, 2 \mathrm{H}$ of $-\mathrm{NH}_{2}$ and $\mathrm{PhCH}_{2}-$ appeared at $\delta 4.03$ to 4.10 and 3.58 to 3.80 , respectively, with singlet for all complexes. The aromatic protons appeared with their specific peak from $\delta 7.32$ to $7.59(J=7$ to 8$)$. In ${ }^{13} \mathrm{C} \mathrm{NMR}$, the benzyl carbon $\left(\mathrm{PhCH}_{2}-\right)$ at $\delta 45.43$ to 43.59 ranges for all the $\left(\mathrm{PdCl}(\mathrm{BLs})_{2}\right)$ complexes [19]. The aromatic ortho, meta, and para $-\mathrm{Cl}$ attached carbon appeared within $\delta 145.722$ to 128.6 for the complexes. The carbon of $-\mathrm{Cl}$ at ortho, meta, and para appeared at $\delta 132.2,128.5$, and 129.69 ppm, respectively. The +ve ESI mass spectra of Pd complexes have found $[\mathrm{M}+$ 1] confirming their molecular mass. The UV/Vis absorption from 265 to $270 \mathrm{~nm}$ and ${ }^{1} \mathrm{H}$ NMR coupling constant between 5 and $9 \mathrm{MHz}$ have confirmed their trans geometry (Figure 2) [20-22].

4.2. Absorption Spectroscopy. To investigate a solid state structure retained in solution, the UV/Vis spectral behaviour was investigated in DMSO and DMSO + water as well as in $\mathrm{DMSO}+$ phosphate buffer for $\mathrm{PdCl}(\mathrm{BLs})_{2}$. The overall patterns of spectra for complexes solution were found similar to different mediums to ensure their molecular sustainability 


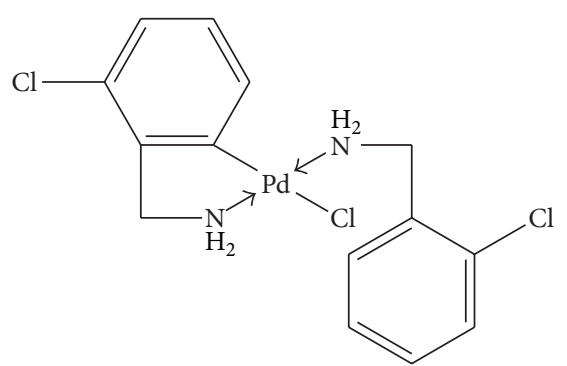

$\operatorname{Pd} 2 \mathrm{CBA}$

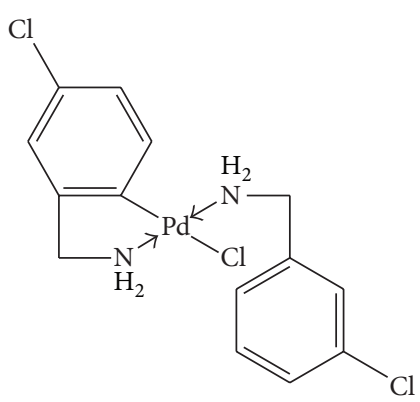

Pd3CBA

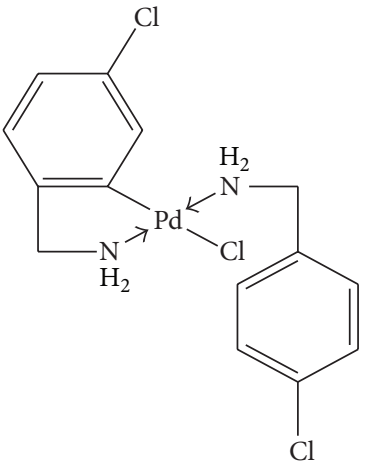

Pd4CBA

FIGURE 2: Structure of synthesized Pd (II) complexes.

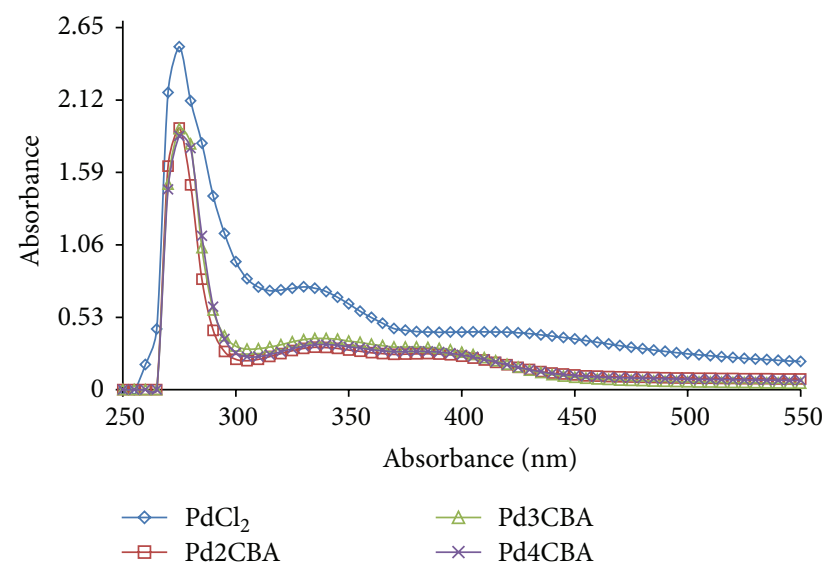

FIgURE 3: UV spectra of Pd (II) complexes in DMSO at $0.001 \mathrm{M}$.

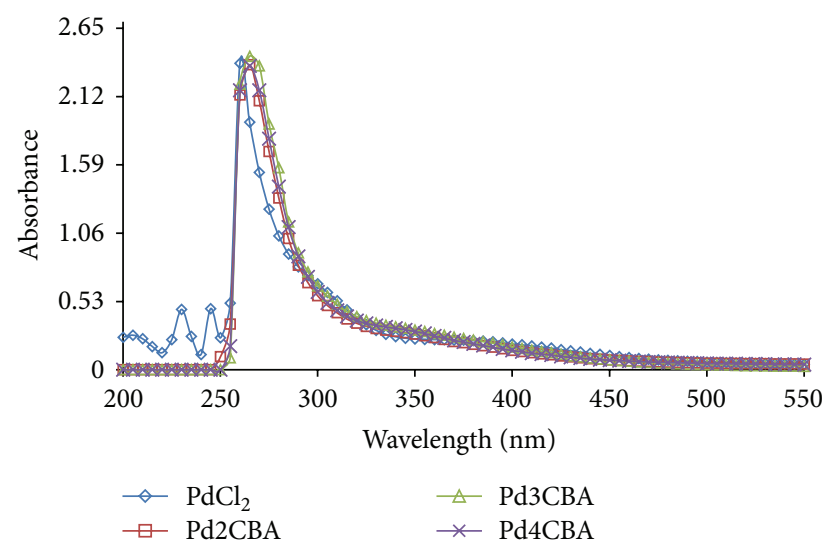

FIGURE 4: UV spectra of Pd (II) complexes in DMSO : water.

in different solvents. The absorption spectrum consists of a band at $400 \mathrm{~nm}$ and may be assigned as $1 \mathrm{~A}_{1 \mathrm{~g}} \rightarrow 1 \mathrm{~A}_{2 \mathrm{~g}}\left(d_{x y} \rightarrow\right.$ $d_{x^{2}-y^{2}}$ ) transition occurring with Pd complexes (Figures 3-5) [23]. The UV/Vis absorption band from 265 to $270 \mathrm{~nm}$ has confirmed their trans geometry of the $\mathrm{PdCl}(\mathrm{BLs})_{2}$ [20-22].

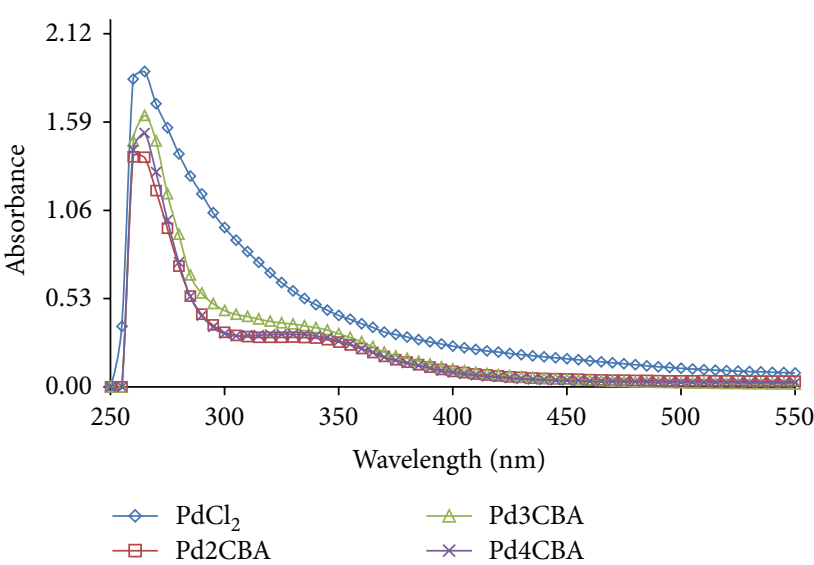

FIGURE 5: UV spectra of Pd (II) complexes in DMSO : phosphate buffer at $7.2 \mathrm{pH}$.

4.3. SAED Pattern through HRTEM. The TEM images reports from the SAED pattern were taken at different magnification suggesting the presence of different elements which are semicrystalline and homogeneous in shape (Figure 6, ESI Figures S1 and S2 in Supplementary Material available online at http://dx.doi.org/10.1155/2016/4359375). The proper alignment is not seen in the rings which indicate that the complex is not completely crystalline but a clear formation of rings suggesting the semicrystalline nature of complexes.

\subsection{Biological Potential}

4.4.1. Antimicrobial Activity. Biological evaluation was made by Kirby Beurs Disc Diffusion Method as per standard procedure $[24,25]$. The $\mathrm{PdCl}(\mathrm{BLs})_{2}$ gave best response against Gram-negative (E. coli and P. aeruginosa) and Gram-positive (S. aureus and B. subtilis) microbes (Figure 7, Table 1). All Pd (II) complexes are not effective against the fungal microbes (C. albicans and A. niger) and they have not shown any zone of inhibition. The biological evaluation inferred that the $\mathrm{PdCl}(\mathrm{BLs})_{2}$ showed greater activity against positive organisms and less activity against negative organisms. 


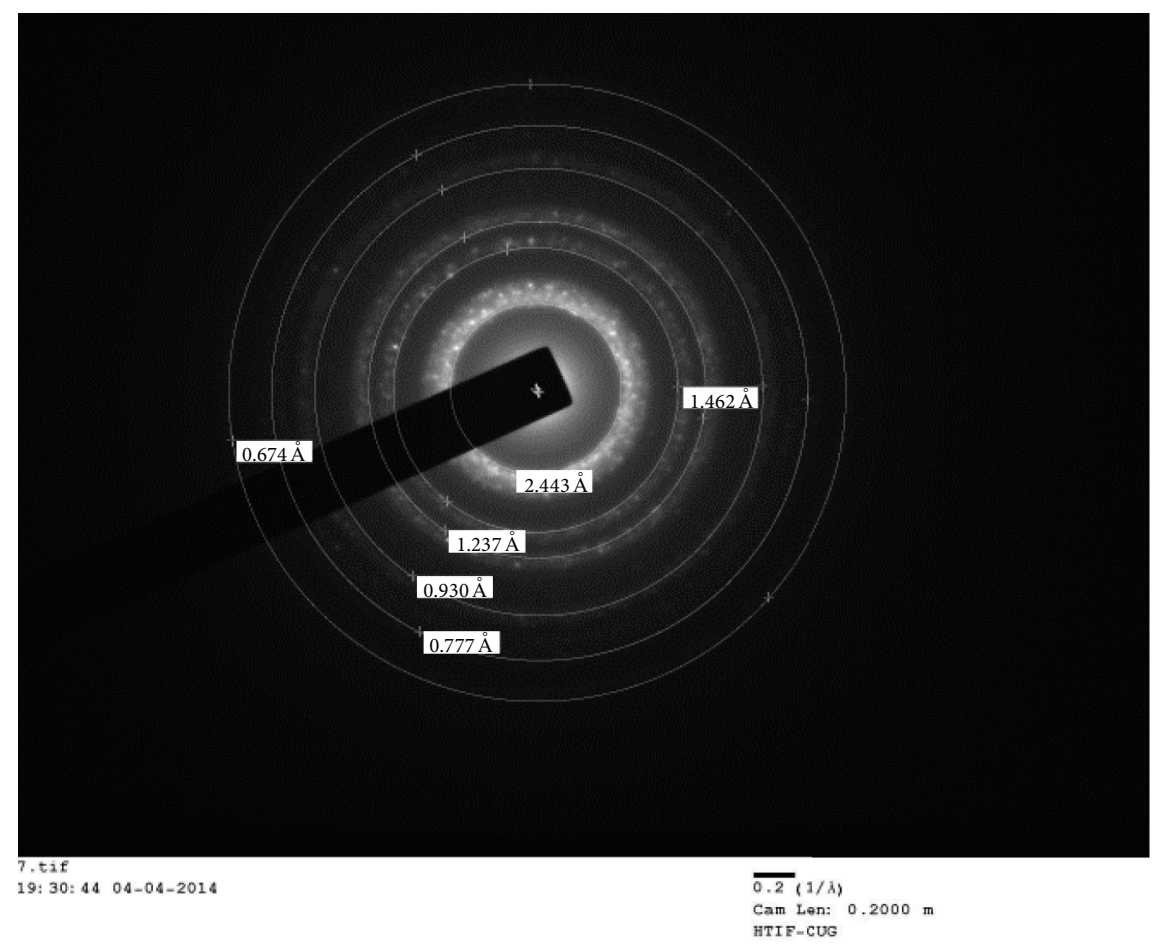

Figure 6: SAED pattern of Pd2MBA.

TABle 1: Antimicrobial activity of Pd (II) complexes.

\begin{tabular}{lcccccc}
\hline \multirow{2}{*}{$\begin{array}{l}\text { Complexes } \\
\text { Staphylococcus aureus }\end{array}$} & Bacillus subtilis & Escherichia coli & Pseudomonas aeruginosa & $\begin{array}{c}\text { Fungi (yeast) } \\
\text { Candida albicans }\end{array}$ & $\begin{array}{c}\text { Fungi (mould) } \\
\text { Aspergillus niger }\end{array}$ \\
\hline Pd2CBA & 5.25 & 7.76 & 7.98 & 6.99 & - & - \\
Pd3CBA & 6.98 & 8.23 & 9.1 & 8.09 & - & - \\
Pd4CBA & 7.79 & 8.15 & 8.76 & 6.27 & - & - \\
Chloramphenicol & 28.67 & 24.44 & 29.63 & 26.30 & NA & NA \\
Ciprofloxacin & 21.11 & 22.23 & 22.33 & 21.34 & NA & NA \\
Amphotericin-B & NA & NA & NA & NA & 14.23 & 15.34 \\
\hline
\end{tabular}

4.4.2. Antioxidant Activities. The scavenging activities have been investigated to support the biological potential of $\operatorname{PdCl}(\mathrm{BLs})_{2}[26,27]$. The antioxidant activities have been studied with analyzing the decrease in absorbance or scavenging effect of a stable free $\mathrm{DPPH}^{\circ}$ as per standard procedure for the $\mathrm{PdCl}(\mathrm{BLs})_{2}[28,29]$. The percentage scavenging activity of Pd (II) complexes has been determined in a concentrationdependent mode in comparison to the $\mathrm{DPPH}^{\bullet}$ absorption at $517 \mathrm{~nm}$ [30-32]. The $\mathrm{DPPH}^{\bullet}$ free radical's absorption at $517 \mathrm{~nm}$ with DMSO was 0.906 for Pd (II) complexes. From 50 to $250 \mu \mathrm{M}$ with an interval of $50 \mu \mathrm{M}$, complexes have expressed a decrease in absorption (Figure 8) that characterized them as antioxidant.

The highest 94.49, 72.36, and 70.79\% for Pd2CBA, Pd3CBA, and Pd4CBA, respectively, inferred Pd2CBA a strong antioxidant among them. The obtained values also compared with the control ascorbic acid which inferred that the results are very closer to control range. Thus, the antioxidant activities of Pd complexes have inferred their significance in medicinal as well as material sciences.

\section{Conclusion}

Genome studies have provided a better understanding of the closer distance between the microbial kingdom and the human species. The synthesized $\mathrm{PdCl}(\mathrm{BLs})_{2}$ complexes showed selective and moderate activity against different microbes and the interesting results were obtained for Grampositive species, which are common in the environment. Apart from their microbial studies, the complexes have also expressed significant free radical-scavenging activities acting as antioxidants and could be used for medicinal purposes. However, in present study, we have focused on their antimicrobial and antioxidant activities and their other activities relevant to medical, biophysical, and biochemical processes are being pursued. The anticancer activity on suitable cell line 


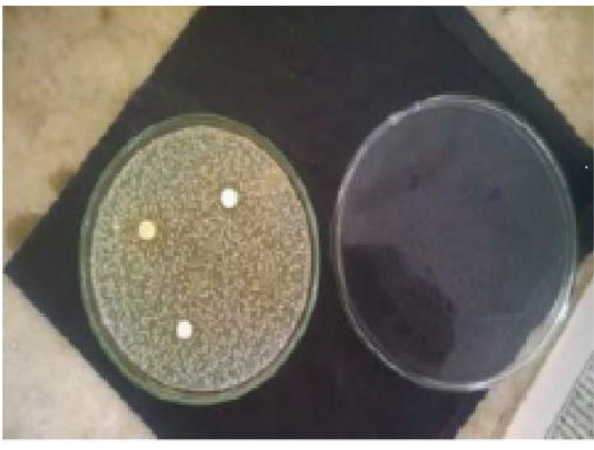

S. aureus

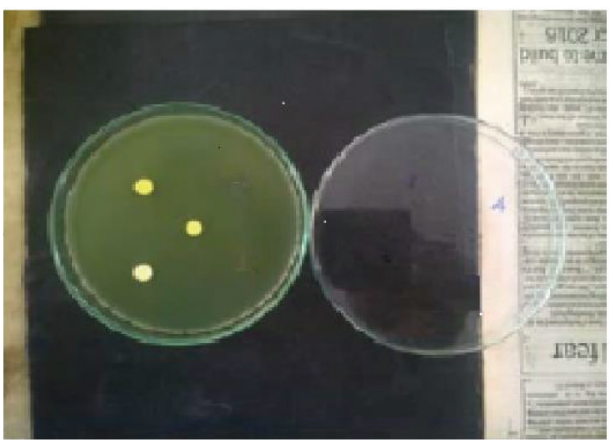

P. aeruginosa

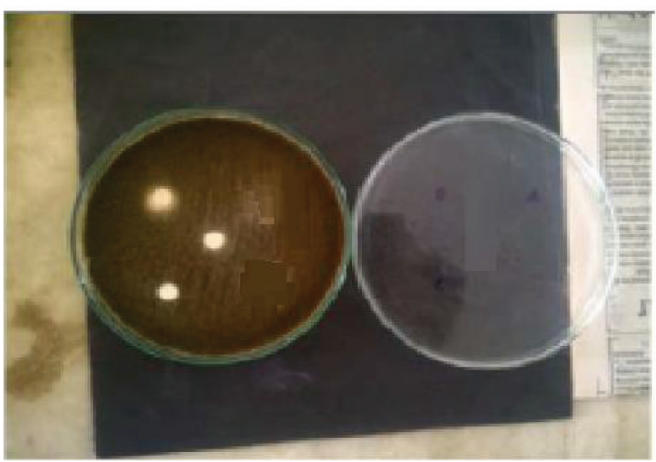

A. niger

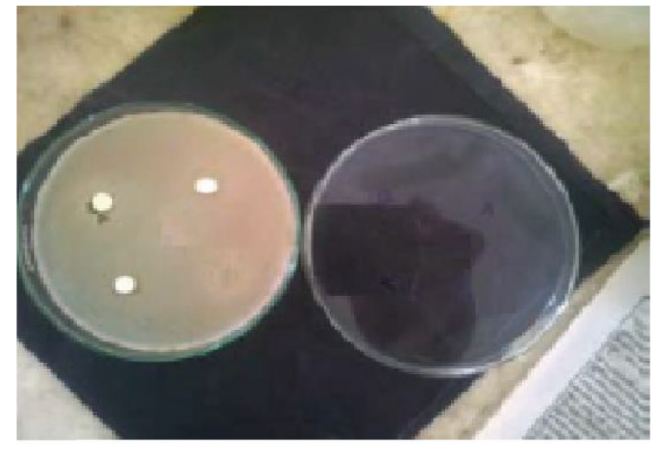

B. subtilis

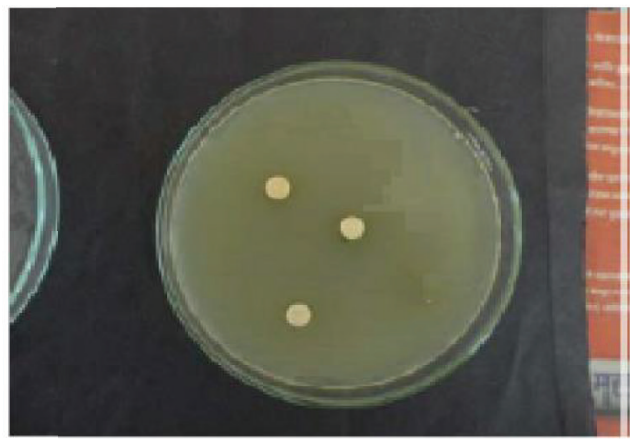

E. coli

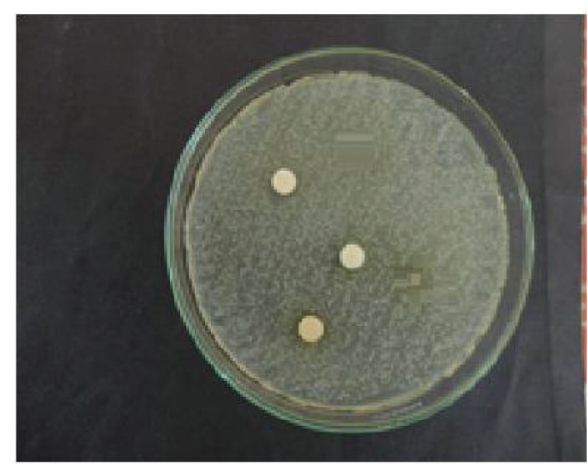

C. albicans

Figure 7: Antimicrobial studies of Pd (II) complexes.

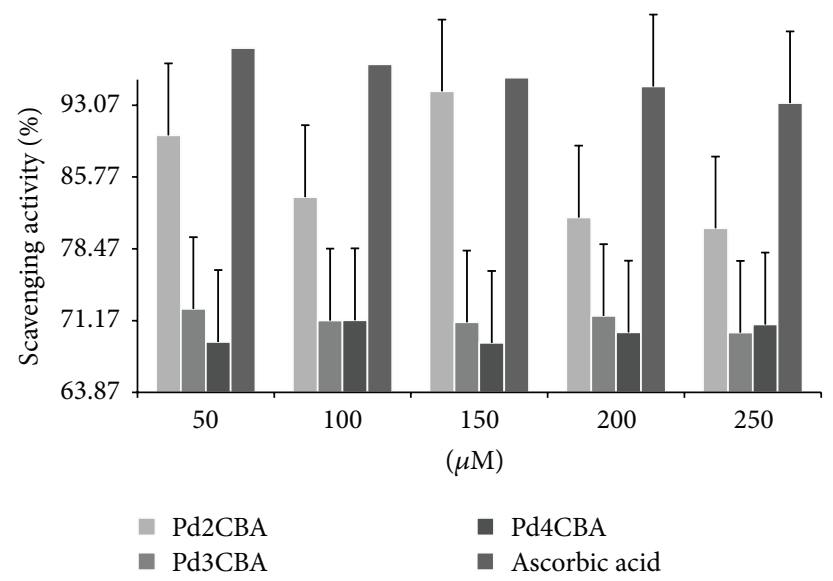

FIGURE 8: Free radical-scavenging activities of synthesized complexes. 
against solid tumours, apoptosis, and DNA binding studies are under progress.

\section{Competing Interests}

The authors declare that there are no competing interests regarding the publication of this paper.

\section{Acknowledgments}

The authors are thankful to Central University of Gujarat, Gandhinagar, for financial and infrastructural support and experimental facilities.

\section{References}

[1] B. Taqui Khan, K. Najmuddin, S. Shamsuddin, K. Annapoorna, and J. Bhatt, "Synthesis, antimicrobial, and antitumor activity of a series of palladium(II) mixed ligand complexes," Journal of Inorganic Biochemistry, vol. 44, no. 1, pp. 55-63, 1991.

[2] L. Tušek-Božić, A. Furlani, V. Scarcia, E. De Clercq, and J. Balzarini, "Spectroscopic and biological properties of palladium(II) complexes of ethyl 2-quinolylmethylphosphonate," Journal of Inorganic Biochemistry, vol. 72, no. 3-4, pp. 201-210, 1998.

[3] M. Galanski, "Recent developments in the field of anticancer platinum complexes," Recent Patents on Anti-Cancer Drug Discovery, vol. 1, no. 2, pp. 285-295, 2006.

[4] E. Gao, C. Liu, M. Zhu, H. Lin, Q. Wu, and L. Liu, "Current development of $\mathrm{Pd}(\mathrm{II})$ complexes as potential antitumor agents," Anti-Cancer Agents in Medicinal Chemistry, vol. 9, no. 3, pp. 356-368, 2009.

[5] K. S. Prasad, L. S. Kumar, S. Chandan, R. M. Naveen Kumar, and H. D. Revanasiddappa, "Palladium(II) complexes as biologically potent metallo-drugs: synthesis, spectral characterization, DNA interaction studies and antibacterial activity," Spectrochimica Acta. Part A, vol. 107, pp. 108-116, 2013.

[6] C. Navarro-Ranninger, F. Zamora, J. R. Masaguer, J. M. Pérez, V. M. González, and C. Alonso, "Palladium(II) compounds of putrescine and spermine. Synthesis, characterization, and DNA-binding and antitumor properties," Journal of Inorganic Biochemistry, vol. 52, no. 1, pp. 37-49, 1993.

[7] I. Brudziñska, Y. Mikata, M. Obata, C. Ohtsuki, and S. Yano, "Synthesis, structural characterization, and antitumor activity of palladium(II) complexes containing a sugar unit," Bioorganic and Medicinal Chemistry Letters, vol. 14, no. 10, pp. 2533-2536, 2004.

[8] A. Garoufis, S. K. Hadjikakou, and N. Hadjiliadis, "Palladium coordination compounds as anti-viral, anti-fungal, antimicrobial and anti-tumor agents," Coordination Chemistry Reviews, vol. 253, no. 9-10, pp. 1384-1397, 2009.

[9] W. Guerra, E. de Andrade Azevedo, A. R. de Souza Monteiro et al., "Synthesis, characterization, and antibacterial activity of three palladium(II) complexes of tetracyclines," Journal of Inorganic Biochemistry, vol. 99, no. 12, pp. 2348-2354, 2005.

[10] L. M. M. Vieira, M. V. de Almeida, M. C. S. Lourenço, F. A. F. M. Bezerra, and A. P. S. Fontes, "Synthesis and antitubercular activity of palladium and platinum complexes with fluoroquinolones," European Journal of Medicinal Chemistry, vol. 44, no. 10, pp. 4107-4111, 2009.
[11] D. Kovala-Demertzi, M. A. Demertzis, J. R. Miller, C. Papadopoulou, C. Dodorou, and G. Filousis, "Platinum(II) complexes with 2-acetyl pyridine thiosemicarbazone: synthesis, crystal structure, spectral properties, antimicrobial and antitumour activity," Journal of Inorganic Biochemistry, vol. 86, no. 2-3, pp. 555-563, 2001.

[12] R. R. Coombs, M. K. Ringer, J. M. Blacquiere et al., "Palladium(II) Schiff base complexes derived from sulfanilamides and aminobenzothiazoles," Transition Metal Chemistry, vol. 30, no. 4, pp. 411-418, 2005.

[13] I. Kizilcikli, Y. D. Kurt, B. Akkurt et al., "Antimicrobial activity of a series of thiosemicarbazones and their $\mathrm{Zn}$ (II) and $\mathrm{Pd}(\mathrm{II})$ complexes," Folia Microbiologica, vol. 52, no. 1, pp. 15-25, 2007.

[14] N. M. Aghatabay, M. Somer, M. Senel, B. Dulger, and F. Gucin, "Raman, FT-IR, NMR spectroscopic data and antimicrobial activity of bis[ $\mu_{2}$-(benzimidazol-2-yl)-2-ethanethiolato- $N, S, S$ chloro-palladium(II)] dimer, $\left[\left(\mu_{2}-\mathrm{CH}_{2} \mathrm{CH}_{2} \mathrm{NHNCC}_{6} \mathrm{H}_{4}\right) \mathrm{PdCl}\right]_{2}$. $\mathrm{C}_{2} \mathrm{H}_{5} \mathrm{OH}$ complex," European Journal of Medicinal Chemistry, vol. 42, no. 8, pp. 1069-1075, 2007.

[15] M. K. Biyala, K. Sharma, M. Swami, N. Fahmi, and R. V. Singh, "Spectral and biocidal studies of palladium(II) and platinum(II) complexes with monobasic bidentate Schiff bases," Transition Metal Chemistry, vol. 33, no. 3, pp. 377-381, 2008.

[16] K. Lemma, S. K. C. Elmroth, and L. I. Elding, "Substitution reactions of $[\mathrm{Pt}(\text { dien }) \mathrm{Cl}]^{+},[\mathrm{Pt}(\text { dien })(\mathrm{GSMe})]^{2+}$, cis- $\left[\mathrm{PtCl}_{2}\left(\mathrm{NH}_{3}\right)_{2}\right]$ and cis- $\left[\mathrm{Pt}\left(\mathrm{NH}_{3}\right)_{2}(\mathrm{GSMe})_{2}\right]^{2+}(\mathrm{GSMe}=S$-methylglutathione $)$ with some sulfur-bonding chemoprotective agents," Journal of the Chemical Society, Dalton Transactions, no. 7, pp. 1281-1286, 2002.

[17] Y. Sun, S. Gou, R. Yin, and P. Jiang, "Synthesis, antiproliferative activity and DNA binding study of mixed ammine/cyclohexylamine platinum(II) complexes with 1-(substituted benzyl) azetidine-3, 3-dicarboxylates," European Journal of Medicinal Chemistry, vol. 46, no. 10, pp. 5146-5153, 2011.

[18] A. D. Allen and C. V. Senoff, "Preparation and infrared spectra of some ammine complexes of ruthenium(II) and ruthenium(III)," Canadian Journal of Chemistry, vol. 45, no. 12, pp. 1337-1341, 1967.

[19] N. D. Ball, J. W. Kampf, and M. S. Sanford, "Synthesis and reactivity of palladium(II) fluoride complexes containing nitrogendonor ligands," Dalton Transactions, vol. 39, no. 2, pp. 632-640, 2010.

[20] L. E. Mihajlović, A. Savić, J. Poljarević et al., "Novel methylene modified cyclohexyl ethylenediamine- $\mathrm{N}, \mathrm{N}^{\prime}$-diacetate ligands and their platinum (IV) complexes. Influence on biological activity," Journal of Inorganic Biochemistry, vol. 109, pp. 40-48, 2012.

[21] H. Varbanov, S. M. Valiahdi, A. A. Legin et al., "Synthesis and characterization of novel bis(carboxylato)dichloridobis(ethylamine)platinum(IV) complexes with higher cytotoxicity than cisplatin," European Journal of Medicinal Chemistry, vol. 46, no. 11, pp. 5456-5464, 2011.

[22] M. Navarro, W. Castro, A. R. Higuera-Padilla et al., "Synthesis, characterization and biological activity of trans-platinum(II) complexes with chloroquine," Journal of Inorganic Biochemistry, vol. 105, no. 12, pp. 1684-1691, 2011.

[23] L. Trynda, D. Kwiatkowska, and W. Tyran, "Platinum complexes and pyruvate kinase activity," General Physiology and Biophysics, vol. 17, no. 1, pp. 25-36, 1998.

[24] N. K. Sharma, R. K. Ameta, and M. Singh, "Biological impact of Pd (II) complexes: synthesis, spectral characterization, in vitro anticancer, CT-DNA binding, and antioxidant activities," 
International Journal of Medicinal Chemistry, vol. 2016, Article ID 9245619, 10 pages, 2016.

[25] N. K. Sharma, R. K. Ameta, and M. Singh, "Synthesis, characterization, anticancer, DNA binding and antioxidant studies of benzylamine supported Pd (II) complex," Cancer Medicine \& Anti Cancer Drugs, vol. 1, article 101, 2015.

[26] D. Meyerstein, "Comment on the section: "Antioxidant measurements and hydroxyl radical scavenging activity" in synthesis, characterization, DNA binding, and antioxidant activities of four copper(II) complexes containing N-(3-hydroxybenzyl)amino amide ligands, by Zhi Li-Hua, Wu Wei-Na, Wang Yuan, Sun Guang, J. Coord. Chem., 66, 227 (2013)," Journal of Coordination Chemistry, vol. 66, no. 12, pp. 2076-2078, 2013.

[27] K. Jomova, S. Baros, and M. Valko, "Redox active metalinduced oxidative stress in biological systems," Transition Metal Chemistry, vol. 37, no. 2, pp. 127-134, 2012.

[28] Z. A. Taha, A. M. Ajlouni, W. Al Momani, and A. A. Al-Ghzawi, "Syntheses, characterization, biological activities and photophysical properties of lanthanides complexes with a tetradentate Schiff base ligand," Spectrochimica Acta. Part A, vol. 81, no. 1, pp. 570-577, 2011.

[29] R. Trivedi, S. B. Deepthi, L. Giribabu et al., "Synthesis, crystal structure, electronic spectroscopy, electrochemistry and biological studies of ferrocene-carbohydrate conjugates," European Journal of Inorganic Chemistry, vol. 13, pp. 2267-2277, 2012.

[30] D. Suh and J. B. Chaires, "Criteria for the mode of binding of DNA binding agents," Bioorganic and Medicinal Chemistry, vol. 3, no. 6, pp. 723-728, 1995.

[31] F.-H. Li, G.-H. Zhao, H.-X. Wu et al., "Synthesis, characterization and biological activity of lanthanum(III) complexes containing 2-methylene-1,10-phenanthroline units bridged by aliphatic diamines," Journal of Inorganic Biochemistry, vol. 100, no. 1, pp. 36-43, 2006.

[32] M. E. Howe-Grant and S. J. Lippard, "Aqueous platinum (II) chemistry: binding to biological molecules," Metal Ions in Biological Systems, vol. 20, pp. 63-125, 1980. 

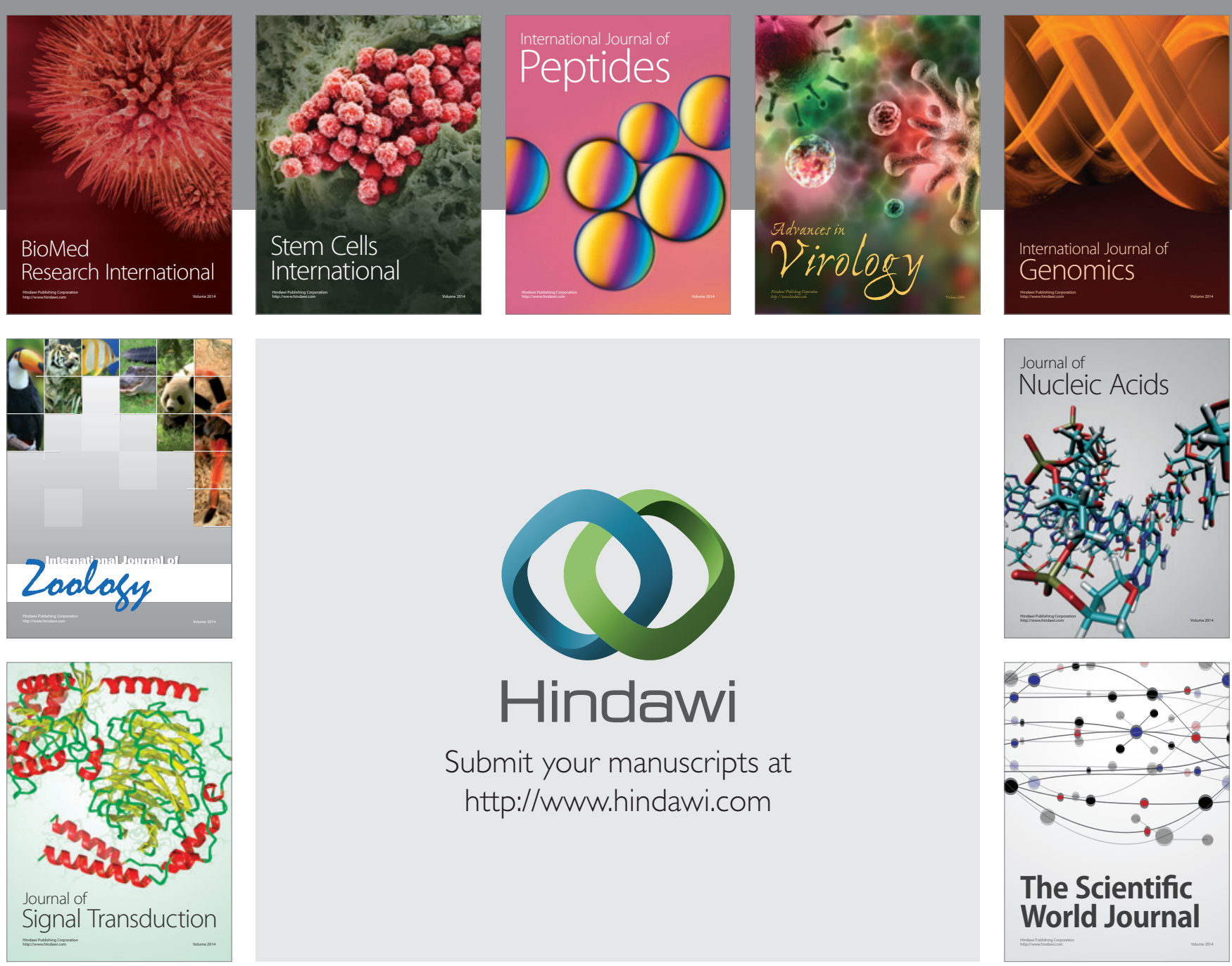

Submit your manuscripts at

http://www.hindawi.com
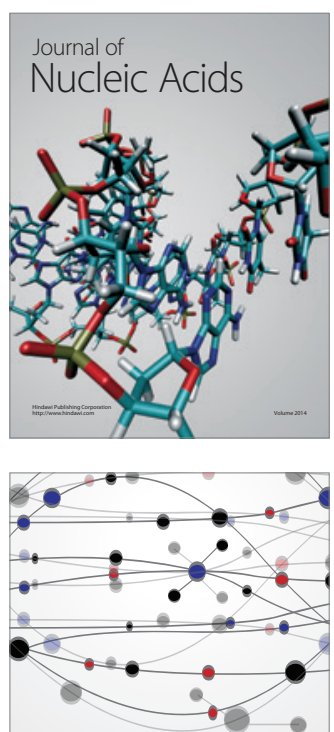

The Scientific World Journal
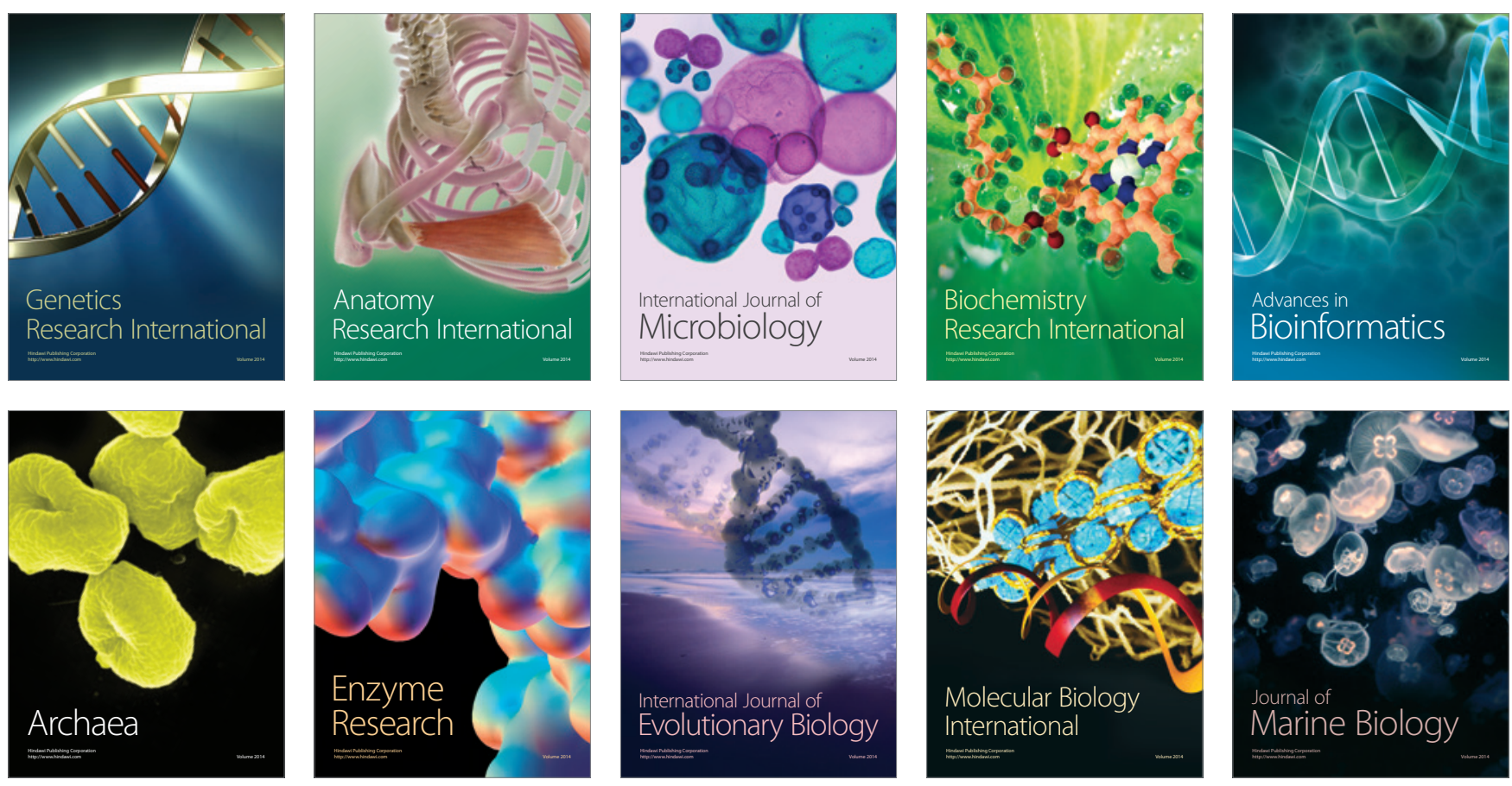